\title{
全硫黄，全窒素，全有機炭素からみた高岡平野完新世堆積物の 堆積環境評価
}

\author{
亀井健史 ${ }^{*}$ 石原廣和 ${ }^{* *}$ ・近藤英昭 ${ }^{* *}$
}

\begin{abstract}
要 旨
高知県高岡平野において，ボーリングにより採取した堆積物に対して全硫黄 (TS) ・全窒素 (TN) ・ 全有機炭素(TOC)を CNS 元素分析を 行うことにより求め, 地球化学的性質の深度分布を明らかにした. また, CNS 元素分析結果から得られる TS と C/S 比が堆積環境(淡水 成・汽水成・海成)評価にとくに有意であることが示唆された，以上のことから本報告では，堆積環境評価における CNS 元素分析結果の 有用性を指摘している。

さらに, これら地球化学的データを加味して, 完新世における海水準変動に伴う海進・海退や河川の影響等によって形成された高岡平 野の古環境変遷を推定した。
\end{abstract}

Key words : CNS 元素分析 CNS elemental analysis, 完新世 Holocene, 堆積環境 sedimentary environment

\section{1. は じめに}

第四紀は，周期的な気候変動(水期一間水期サイクル)が 特徴となっている時代である。その気候変動により水河性 海水準変動が起こり，沖積平野や沿岸域では，たとえ同一 地点においても, 堆積物は異なる堆積環境(淡水域・汽水 域・海水域)下で堆積している。このような堆積環境の変 化は，その堆積層に記録されている。

一般に, 地盤の堆積環境を推定する代表的な手法として は, 古生物学的・堆積学的手法がこれまでよく使われてき たが, 最近では地球化学的性質の有効性む指摘されるよう になってきた ${ }^{1) 31}$. この背景としては, 古生物学的・堆積 学的手法では, 専門的な知識や長年の経験, さらには長時 間を必要とするといった問題点が挙げられる ${ }^{1)}$. そこで今 日, 簡易的・定量的にかつ短時間で堆積環境を評価できる 可能性のある地球化学的成分 (とくに全有機炭素 (TOC) ・ 全窒素 $(\mathrm{TN})$ ・全硫黄 $(\mathrm{TS}))$ を利用した手法が，工学的な 分野への応用面も考慮して有意であるという研究例が報告 されている1) 3).

一方，地盤工学においては未固結地盤への地形地質情報

*島根大学総合理工学部地球資源環境学科 Department of Geoscience, Shimane University (会員)

**(社)日本建設機械化研究所 Japan Construction Method and Machinery Research Institute(会員)

$* * *$ 長浜市役所 Nagahama City Office
の本格的な適用が 1950 年代の東海道新幹線の路線調査を 皮切りに行われ始めてきた4).このような研究成果は, そ の後の地盤工学の発展に多大な貢献をしたといえる。その 結果, 現在では未固結地盤の土質試験結果の解釈に際して は, 正確な地質層序区分はきわめて重要であると認識され ている.

以上のことから, 第四紀地質学から得られる地質情報を 理解し, 適切な地層断面を作成することは, 土質試験結果 の評価を行う場合においても，重要な判断基準となる。今 後, ますます建設対象が大規模な丘陵地や沖合へ展開され るにしたがって, 第四紀地質学を中心とした研究がより重 要な分野となってくる. そのため, 地盤工学と第四紀地質 学はこれまでのように個々の分野で地盤を研究するのでは なく，境界領域を超えた理工融合的な研究を行うことがき わめて重要であると考えられる。

本研究では, 既往の研究内容 ${ }^{1) \sim 33}$ をさらに進展するため, 高知県高岡平野の完新世堆積物の堆積環境をその地球化学 的性質を中心に古環境変遷という観点から解明することを 試みた. 高知県高岡平野を対象とした根拠は, 高岡平野が 典型的なおぼれ谷地形を呈し, 仁淀川の自然堤防で閉塞さ れた支谷閉塞低地(一般に泥炭を含む軟弱地盤)が広く発達 している点がまず挙げられる. また, この地域は, 海水準 変動の影響を大きく受けたため, 堆積環境が大きく移り変 わってきていることが知られている ${ }^{5)}$ ）. 分析は, 原位置 より採取した土質試料に対して, TOC・TN・TSに代表 
される地球化学的分析を行い，その結果を既往の研究例と 比較検討することによって地球化学的デー夕から推定され る堆積環境の有用性を指摘した。また，この地域の地理 (海水準変動)・地形・地史の総合的な考察を行い，学際的 な観点から高岡平野完新世堆積物の古環境変遷を解明した.

\section{2. 高岡平野の地形・地質概説}

高岡平野は，仁淀川の支流である波介川によって形成さ れ，山地とその間の谷を埋めるように広がる沖積低地であ る(図-1)。平野の北側には，西端の虚空蔵山(674m)を最 高峰として，東方に連なる約 $400 \mathrm{~m}$ 以下の山地・丘陵が分 布する。また, この平野の南側においても, 約 $300 \mathrm{~m}$ 程度 の山地・丘陵が東方に連なり, 最高峰は御領寺山の $306 \mathrm{~m}$ である ${ }^{5)}$ 。このような地形が形成された理由として，この 地域の地質構造が東西性の構造線によって帯状配列をして いることが挙げられる，また，高位・中位・低位の $3 つ の$ 段丘面が分布し，さらに，波介川沿岸に沖積平野である高 岡平野が位置している。なお，平野部においては，波介川 流域に標高 5 $8 \mathrm{~m}$ 程度の平坦面が広く分布する。この低 地は，比較的平坦で仁淀川の後背湿地に相当すると考えら れる7). 波介川は東西性の河川であり, 総延長は約 $20 \mathrm{~km}$ である．また，西方約 $8 \mathrm{~km}$ の甲原付近で甲原川と分岐す る.

一方，多数の南北性の小河川が波介川に流入している。 また，山地の山裾部と平野部の境界は明瞭であり，典型的 なおぼれ谷地形を呈している，そのため，平野部の基盤岩 はかなり起伏に富んでいると推定される。

高岡平野は, 西南日本外帯の四万十帯の北縁部に位置し, 北側の山地には, 秩父帯之四万十帯の境界線である仏像構 造線が分布する．また，高岡平野には，白亜系からなる基 盤岩の上位に第四紀の堆積物が不整合関係で堆積している. この地域に分布している白亜系は，新土居層と呼ばれ，主 に砂岩・頁岩およびそれらの互層からなる，第四系は，上 部更新統の中川内層之完新統の波介層からなる ${ }^{5)}$. 中川内 層は高岡平野の地下に広く分布する低位段丘堆積物いわゆ

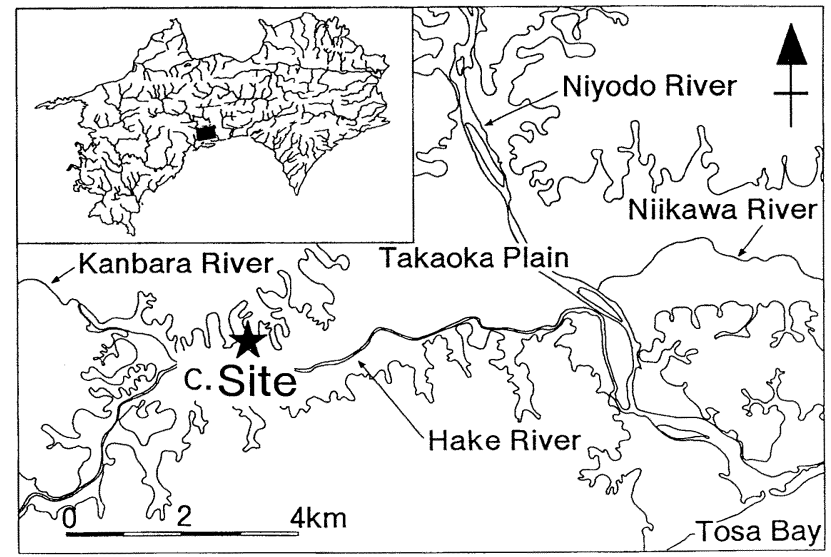

図-1＼cjkstart試料採取地点
る洪積第一礫層 ${ }^{5}$ からなり, 層厚は約 $5 \mathrm{~m}$ である。この層 は東方に連続しており，仁淀川付近できわめて厚くなる. また，波介層は中川内層の上位に不整合関係で堆積してお り，層厚は最大約 $30 \mathrm{~m}$ である，大部分が泥層であり，平 野の西部と中央部では上部付近に砂層を挟んでいる。また， 波介層中部には音地火山灰を挟在する火山灰質砂層があり， その最大の層厚は約 $5 \mathrm{~m}$ である ${ }^{5)}$. 本研究では，主に波介 層を対象とする。

\section{3. 試料および分析・試験方法}

\section{1 試料}

高岡平野西部の C 地点において深度 $20 \mathrm{~m}$ のボーリング が実施された ${ }^{7), 8)}$. 調査地点の地形図を図-1に，一般的に 実施されている粒度試験，試料の観察に基づいた土層構成 を図-2に示す。その試料は記載の後, CNS 分析と火山洃 分析に使用した。

\section{2 堆積学的・地球化学的分析手法}

堆積学的分析として火山灰分析を, 地球化学的分析とし て全有機炭素濃度 $(\mathrm{TOC}) \cdot$ 全窒素濃度 $(\mathrm{TN}) \cdot$ 全硫黄濃度 （TS）を測定した.

火山灰分析は，深度 $12.5 ， 13 ， 13.5 ， 14 ， 14.5 \mathrm{~m}$ で実施 した，火山灰は以下の方法で抽出した。 まず，試料に水を 加えて十分にかき混ぜ，浮遊しているシルトサイズ以下の 粒子を取り除く。この作業を数回繰り返した後, 超音波洗 浄器を用いて残留している粘土分を取り除く。風乾後，プ レパラートを作成し，鏡下において火山ガラスおよびその

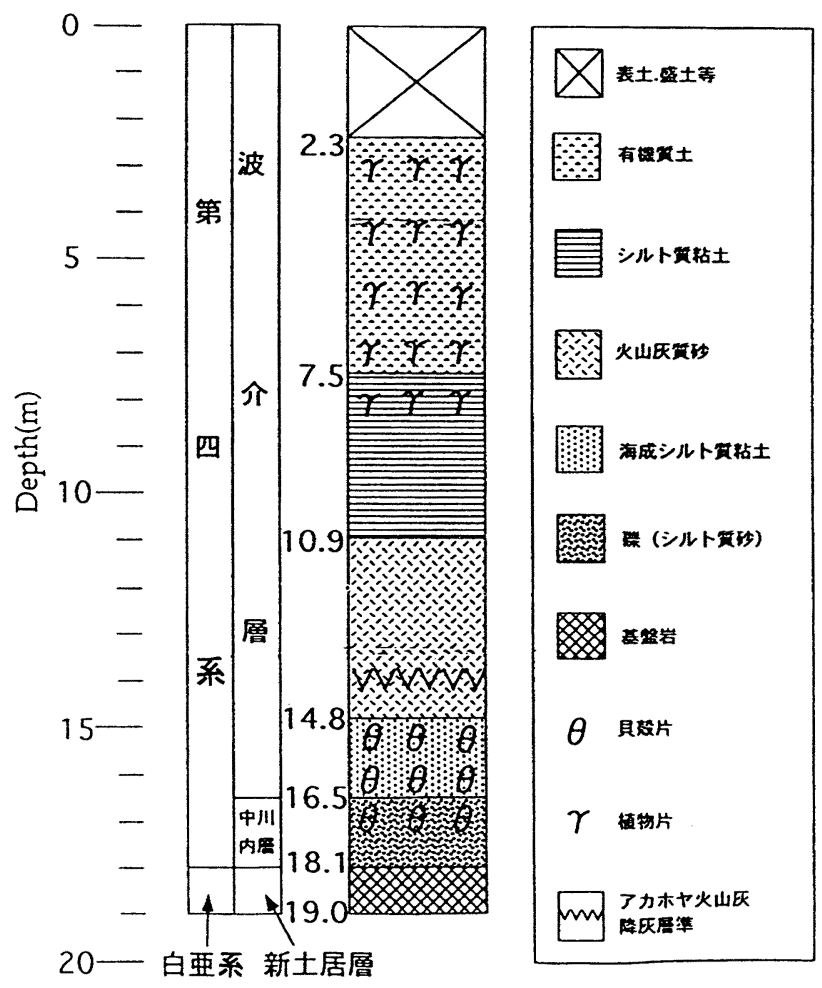

図-2ボーリングによって推定された岩質と層序 
他の鉱物の同定および数量測定を 1 サンプルにつき合計 200 個行った.

$\mathrm{TOC} \cdot \mathrm{TN} ・ \mathrm{TS}$ の測定は, 深度 $1 \mathrm{~m}$ につき $1 \sim 2$ 点行っ た. 試料は約 $80^{\circ} \mathrm{Cで} 24$ 時間乾燥させた後, $200 \mathrm{mesh}$ 程度 に粉砕し，この乾燥試料を約 $12 \mathrm{mg}$ 秤量し， $1 \mathrm{~N}-\mathrm{HCl}$ を添 加し $110^{\circ} \mathrm{C}$ で約 20 分以上乾燥させ, 元素分析計を用いて 燃焼法で測定した ${ }^{1) ~ 3) . ~}$

\section{4. 分析結果および考察}

\section{1 層相と層序区分}

本研究で使用した試料は, 深度 $2.3 \sim 19.0 \mathrm{~m}$ である. 試 料の観察と既往のデータ ${ }^{8)}$ おび火山灰分析の結果から, 大きく 6 つの層が認められ，下位から基盤岩・砂碟層 (シ ルト質砂)・海成シルト質粘土層・火山灰質砂層・シル卜

質粘土層・有機質土とした(図-2).

基盤岩（深度 18.1〜 19.0m）は，黄褐色をした風化砂岩で あり，指圧で砂状，礫状となる．砂碟層(シルト質砂) (深 度 16.5 18.1 m) は，暗灰色の礫混じりのシルト質砂層で あり， $\phi 5 \sim 30 \mathrm{~mm}$ の礫の混入と貝殼片を多産する。 また， 海成シルト質粘土層(深度 $14.8 \sim 16.5 \mathrm{~m}$ ) は, 暗灰色のシル 卜層であり，貝殻片が混入している。 また，層下部で砂分 の混入がみられる。

火山灰質砂層（深度 $10.9 \sim 14.8 \mathrm{~m}$ ）は，上位の火山灰質砂 層と下位のシルト質粘土から構成される，いわゆる“音地” と呼ばれるあのである。深度 $13 \sim 14 \mathrm{~m}$ で深くなるに従い バブルウォール型の淡褐色を呈する火山ガラスの含有量が 増加する傾向が認められ，さらに，深度 $14 \mathrm{~m}$ 付近では 20〜30 cm の濃集層をなしている。一方，深度 $14.5 \mathrm{~m}$ の試 料からは火山ガラスは検出されない。したがって，火山灰
の降下層準は深度 $14 \mathrm{~m}$ 付近であり, その上位は再堆積物 であると判断できる。 また，この降下火山灰は，火山ガラ スの特徴から鬼界アカホヤ火山灰 ${ }^{9), 11}$ であると判断した。 なお，報告書 ${ }^{8}$ によれば，深度 $14 \sim 14.8 \mathrm{~m}$ の層は火山灰質 砂亡なっているが，今回の火山灰分析結果によれば，火山 灰がほとんど涊められず，シルト質粘土が主体であった。 よって，この層は下位の海成シルト層に含まれるものと考 えられる。

シルト質粘土層（深度 $7.5 \sim 10.9 \mathrm{~m}$ ) は，暗色のシルト層 であり, 腐植物が混入している。 さらに, 有機質土(深度 2.3〜 7.5m) は，褐灰〜暗灰色の有機質シルト層であり，全 体に腐植物を多く含んでいる。

\subsection{TOC・TN・TS からみた高岡平野の古環境変遷}

\subsection{1 $\mathrm{TOC} ・ \mathrm{TN} ・ \mathrm{TS}$ の深度変化}

$\mathrm{TOC} ・ \mathrm{TN} ・ \mathrm{TS}, \mathrm{C} / \mathrm{S}$ 比・C/ $\mathrm{N}$ 比の深度分布および CNS 元素分析結果と粒度試験結果等に基づいた総合柱状 図を図-3(a)〜 (c)にそれぞれ示す.

TOC に代表される有機物は，水域に生息する淡水性・ 海洋性プランクトンや河川によって運搬された陸上高等植 物などを起源としている。 また，TSの大部分を占める黄 鉄鉱の形成にあ不可欠である ${ }^{12), 13)}$.

本分析結果(図-3(a)) では，深度 2.5〜 6.5m において, TOC が $5 \%$ 以上で，TN が $0.3 \%$ 以上とかなり高い值を示 している。これは，陸起源の有機質土で構成されているた めと考えられる。

深度 7.5〜 10.5m では, TOC が 1.5〜 1.7\%で，TN が 0.13 〜 $0.14 \%$ の範囲にあるが，この区間はシルト質粘土が堆積 していることから流速エネルギーの低い堆積環境であった ことが推定され，そのような環境では，有機物がある程度
TOC(\%)

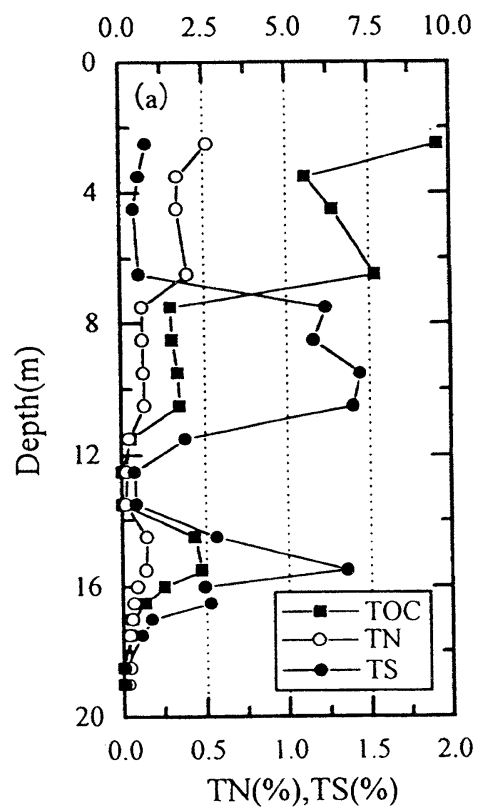

$\mathrm{C} / \mathrm{N}$

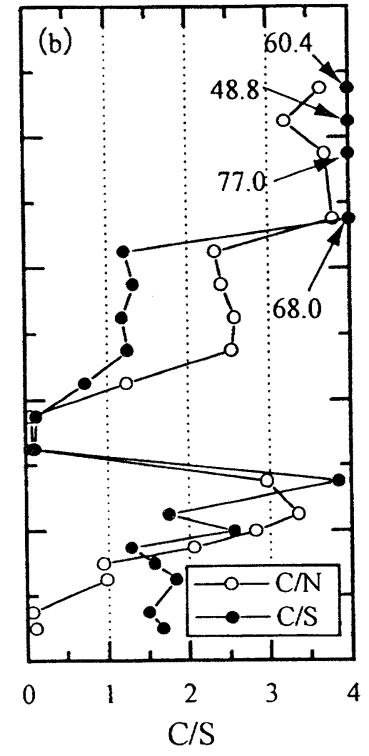

(c)

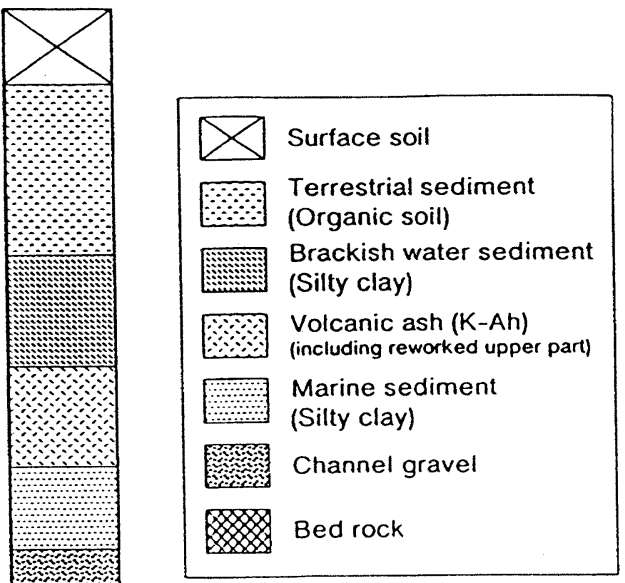

図-3 TOC・TN・TS, C/N 比, C/S 比の深度分布および地球化学的データから推定される堆積環境 
堆積していたということが考えられる.

深度 11.5〜 13.5m にかけて， TOC は0.01〜0.28\%で, TN む0.05\%以下とかなり低い。この区間では，火山灰質 砂で構成されており，有機物はほとんど堆積しなかったと 考えられる.

深度 $14.5 \sim 16.5 \mathrm{~m}$ では，TOC が 1.3〜 2.4\%で，TN が 0.09 0.15\%の範囲にある.この区間は，深度 $7.5 \sim 10.5 \mathrm{~m}$ 区間と同様にシルト質粘土で構成されている. 深度 $7.5 \sim$ $10.5 \mathrm{~m}$ 区間に比べて TOC がやや高く，同区間の堆積環境 より，有機物の供給量が多い環境であったと考えられる。

深度 16.5〜 19.0m にかけて，TOC は 0〜0.7\%で，TN が 0.03〜0.07\%の範囲にあり, 深度の増加とともに減少し ている.これは，この区間が主に高流速エネルギー下で堆 積する砂や磕で構成されているので, 低密度の有機物が堆 積しにくかったために低い值になったと考えられる。

全体的に, TOC 亡 TN の深さ方向への变化傾向は一致 しており, プロファイルの变曲点は $7.5 \mathrm{~m}, 11 \mathrm{~m}, 14 \mathrm{~m}$, $16.5 \mathrm{~m}$ である。これは, 堆積構造・粒度・堆積物によって 区分された地層境界と一致する。

\subsection{2 全硫黄濃度 $(\mathrm{TS})$}

堆積物中において，硫黄は黄鉄鉱の形態で保存される. また，保存された黄鉄鉱は硫酸酸性環境下では分解される が，還元環境下では安定な鉱物である。

黄鉄鉱の形成 ${ }^{12)}{ }^{13)}$ には, 硫酸イオン $\left(\mathrm{SO}_{4}{ }^{2-}\right)$, 有機物, 硫酸還元バクテリア，鉄イオンが必要である。，その中でも， 黄鉄鉱の起源物質である $\mathrm{SO}_{4}{ }^{2-}$ は海水と淡水とではその濃 度が著しく異なる ${ }^{14), 15)}$ ，このことから， $\mathrm{TS}^{16), 17)}$ は海成，陸 成の第一段階の判定指標として有効であると考えられる.

先述の判定指標を基準に本分析結果(図-3(a))を考察す ると，TS は深度 2.5〜 6.5m で 0.08〜 0.16\%の範囲にある ことから，この時期の環境は淡水成であるといえる。深度 7.5〜 10.5m においては，TS が 1.1〜1.4\%の範囲にあるこ とから，この時期は，非淡水成(海水・汽水成)で，還元環 境と推定される. また, 深度 11.5〜 13.5m では, TS が 0.08\% 前後とかなり低い值となっている，その理由として，この 区間は火山性の降下物(火山灰質砂)が急速に堆積するため 炭素が入りにくくなり，その結果有機物の堆積む困難とな り，黄鉄鉱が生成される環境ではなかったことが考えられ る.

深度 14.5〜16.5m においては，TS が 0.5〜 1.3\%の範囲 にあることから，この時期の環境は非淡水成(海水・汽水 成)であるといえる。なお， TS $=0.3 \sim 0.5 \%$ の範囲は淡水 成・非淡水成の境界領域であり，両堆積環境がありうる. 深度 $17.0 \sim 19.0 \mathrm{~m}$ では，TS が 0.1\%以下であるが，TS が 低い理由として，主に高流速エネルギー下で堆積する砂や 磁で構成されているため, 低密度の有機物が堆積しにくい ために黄鉄鉱がほとんど生成されなかったと推定される。
また，砂礫地盤では空隙が多いため，海水中の $\mathrm{SO}_{4}{ }^{2-}$ が捕 獲されにくいため $\mathrm{S}$ が少なくなり，その結果黄鉄鉱が生 成されにくくなっていることも考えられる.

\subsection{3 有機炭素/全硫黄比 $(\mathrm{C} / \mathrm{S}$ 比)}

一般に，C/S 比と呼ばれている TOC と TS の比は，海 成, 淡水成の判定指標に有効であり, 標準的な海成堆積物 の C/S 比は狭い範囲を示している ${ }^{12), 16), 18) ~ 20) . ~ こ の よ う に ~}$ $\mathrm{C} / \mathrm{S}$ 比は海成, 淡水成の判定指標に用いられているが, 固結した堆積岩と未固結堆積物では異なった值を示してい る.この理由としては続成作用による有機炭素の減少や硫 化物の生成が挙げられる ${ }^{21,22)}$.

また，汽水〜海水成の場合には，酸化還元性あある程度 議論することが可能であり， $\mathrm{C} / \mathrm{S}$ 比が 3 前後は酸化的な 海底泥質堆積物, 1 前後は湖底が貧酸素となりやすい汽水 成〜内湾泥質堆積物を示す ${ }^{23)}$. とくに, 汽水成堆積物につ いては, SAMPEI et $a l^{24)}$ や亀井ほが ${ }^{1)}$ にって, C/S $\fallingdotseq 1$ となることが示されている，その理由として，塩分躍層に よる還元的湖底環境之硫酸還元バクテリアに利用されやす い未分解のプランクトン有機物の供給が影響を与えている むのと考えられる.

$\mathrm{C} / \mathrm{S}$ 比の堆積環境評価基準として本研究では $\mathrm{BERNER}^{12)}$ BERNER and RAISWELL ${ }^{18)}$, MORSE and BERNER ${ }^{20)}$ 等が提案した值と本研究の分析結果を基にして，標準的 (酸化的)な海成堆積物の $\mathrm{C} / \mathrm{S}$ 比を $2.8 \pm 0.8$ とし，還元的 な海成堆積物 (汽水成〜内湾堆積物)においては, $\mathrm{C} / \mathrm{S} \fallingdotseq$ $1.1 \pm 0.4$ とする. また, 淡水成堆積物の $\mathrm{C} / \mathrm{S}$ 比を 5 以上 と設定する.

$\mathrm{C} / \mathrm{S}$ 比の分析結果を図-3(b)に示す。図より, 深度 2.5〜 6.5m では, $\mathrm{C} / \mathrm{S}$ が 48 以上と高い值を示す。よって, 淡水成層である。深度 $7.5 \sim 10.5 \mathrm{~m}$ にかけて，C/S 比が 1.1〜1.3の範囲にあり，前述の判定指標によれば，汽水成 〜内湾の泥質堆積物であることが推定できる。また，約 6300 年前の年代指標となる鬼界アカホヤ火山灰の層準が 深度約 $14.0 \mathrm{~m}$ であることや火山灰が堆積しているときに 仁淀川の自然堤防が形成され，その後，その堤防によって 支谷の出口が閉塞され，支谷底が湖沼となっだ(7)ことか ら判断すると, この時期の環境は外海の影響を受ける水域 から，湖沼のような閉鎖的な水域へと変化したと考えられ る. 深度 14.5〜 16.0m において, C/S 比が $1.8 \sim 3.9$ の範囲 にあることから，この時期は海成環境であるといえる。

なお，深度 11.5〜 13.5m と深度 16.5〜 19.0m については， 砂や碟で構成されているため， C/S 比による判定は困難 であった。

\subsection{4 有機炭素/全窒素比 $(\mathrm{C} / \mathrm{N}$ 比 $)$}

海成の有機物は主に動植物プランクトンであり, 淡水成 の有機物は植物プランクトンと陸上高等植物である. 動植 物プランクトンの $\mathrm{C} / \mathrm{N}$ 比(重量比)が約 6〜 7 であるのに 
対し，陸上高等植物はセルロースやリグニンのような $\mathrm{N}$ を含まない有機物が主体を占めており，その $\mathrm{C} / \mathrm{N}$ 比は 15 以上の值を示す ${ }^{15), 25), 26)}$. 中井ほか ${ }^{15)}$ は, $\mathrm{C} / \mathrm{N}$ 比の垂直変動 が海水・汽水・淡水の堆積環境の変動を表していることを 示し, $\mathrm{C} / \mathrm{N}$ 比が海成の有機物と陸成の有機物の割合によ り変動することから, 堆積物の供給源を示す良い判定指標 になることを指摘している.

深度 $2.5 \sim 6.5 \mathrm{~m}$ では，C/ $\mathrm{N}$ 比は 16〜19 の範囲にあるこ とから(図-3(b))，上記の判定指標からすると，この時期 に陸源有機物が多く堆積していたものと考えられる。 また, 試料の観察よりこの区間には腐植物が多量に見られるので, この腐植物が陸源有機物の供給源であると考えられる．深 度 7.5〜 10.5m にかけて, C/N 比は 12 前後とやや高く, 陸源有機物の影響がみられる。ただし，次の計算からプラ ンクトンの生産性屯高くなっているものと考えられる.

今, 仮にプランクトン起源有機物の $\mathrm{C} / \mathrm{N}$ 比を 6 , 陸源 有機物の $\mathrm{C} / \mathrm{N}$ 比を 15 としてプランクトン起源有機物の 割合を計算すると約 $30 \%$ となる，実際には，陸源有機物 の $\mathrm{C} / \mathrm{N}$ 比は 15 よりあ大きいことが多いので， プランク トン起源有機物の割合は約 $30 \%$ 以上と考えられる。その 原因としては，この時期の環境が湖沼であったと指摘され ている(6), . そのため, 湖水之外海水之の交換が制御され, 河川等加流入した栄養塩により富栄養化が起こり，外海 の影響を受ける水域より生物生産量が増したことと, 陸源 有機物の供給が少なくなったためと考えられる.

深度 11.5〜 13.5m においては，C/N 比が $0.3 〜 6.2$ の範 囲にあるが，この区間は火山灰質砂であるために， C/N 比による判定は困難である。深度 $14.5 \sim 16.5 \mathrm{~m}$ では，C/N 比は 14〜16 という高い值を示していることから，陸源有 機物の影響がかなり大きかったとみられる。このことと層 相などを考慮すると，この時期は海進初期の海成であるが 陸源物質の供給の多い環境であったと考えられる.

深度 $17.0 \sim 19.0 \mathrm{~m}$ にかけて，C/N 比は $0.3 \sim 5.0$ の範囲 にあるが，この区間は砂や砂で構成されているために， $\mathrm{C} / \mathrm{N}$ 比による判定は困難である.

\subsection{5 地球化学的データから推定される堆積環境評価の 適用性}

これまでの $\mathrm{C} ・ \mathrm{~N} ・ \mathrm{~S}$ 元素分析による考察と粒度試験結 果等に基づいて堆積環境の検討を行った結果，図-3(C)の ような堆積環境の変遷が推定された。 以下に，その根拠を 説明する。

まず，新土居層に対比される深度 18.1 19.0m は，砂岩 で構成されているため，また中川内層に対比される深度 16.5〜 18.1m は，砂や碟で構成されているために C・N・S による評価が困難である.

波介層基底の深度 14.5 16.5m は, C/S 比から海成堆積 物, $\mathrm{C} / \mathrm{N}$ 比から陸源有機物の供給の多い環境が推定され
る。そして，この区間に貝殼片が見られることや既往のデー 夕から陸源有機物の供給の多い海成層と考えられる.

波介層の下部の深度 $10.9 \sim 14.5 \mathrm{~m}$ は, 火山灰質砂である ために $\mathrm{C} ・ \mathrm{~N} ・ \mathrm{~S}$ による評価が困難である。ただし，この 区間の上部である $11.5 \mathrm{~m}$ 地点は火山灰の二次的堆積の影 響が小さくなったために，TS・TN・TOCがやや高くなっ たと考えられる.

波介層の中部の深度 $7.5 \sim 10.9 \mathrm{~m}$ は， $\mathrm{C} / \mathrm{S}$ 比から汽水成 堆積物と推定される。 また, $\mathrm{C} / \mathrm{N}$ 比から陸源有機物の供 給が多少あり，しかもプランクトンの生産性(基礎生産)む 高かった環境と考えられる.

波介層の最上部にあたる深度 2.3〜 7.5m は，TS から淡 水成と推定され，この区間に多量の腐植物がみられる こ とや既往のデー夕等を考慮に入れて陸成層とした。

\subsection{6 硫黄(TS) と全有機炭素濃度 (TOC)の関係}

従来, $\mathrm{C} / \mathrm{S}$ 比を用いて堆積環境を推定する研究は, 続 成作用を受けて固結した堆積岩を対象とする例が多かった。 また, 続成作用すなわち有機物の分解程度により, 数值の ばらつきむ犬きいため, 未固結堆積物に直接応用すること は困難な点が多かった ${ }^{16), 27)}$. しかし，近年 BERNER and RAISWELL ${ }^{17)}$, LYONS and BERNER ${ }^{28)}$, SAMPEI et $a l .{ }^{24)}$ 等により未固結堆積物の様々な堆積環境 (淡水成, 海 成, 強還元性, 汽水湖堆積物)に打ける硫黄 (硫化物硫黄) と TOC の関係が報告されている(図-4 参照)。このような 既往の研究から, 淡水成堆積物の硫化物硫黄濃度が一定の 值（TS $=0.3 \sim 0.5 \%)$ 以下であるのに対し，海成堆積物は $\mathrm{TS}=0.36 \mathrm{TOC}^{28)}$, 汽水湖堆積物は $\mathrm{TS}=1.16 \mathrm{TOC}^{24)}$, 強還 元性堆積物は $\mathrm{TS}=0.10 \mathrm{TOC}+0.9^{13)}$ の関係が認められる.

図-4 は本研究から得られた分析值をプロットしたもの である．この図では既往の研究成果と今回の分析結果が良 く一致していることが認められる。具体的には, 陸成堆積 物(有機質土), 海成堆積物, 汽水成堆積物がそれぞれ淡水, 海水, 汽水域の範囲内にある。 また, 碟や火山兏は図左下 に位置し, 有機炭素, 窒素, 硫黄をほとんど含まないこと を示している.

\section{3 高岡平野の形成過程}

これまでに述べてきた考察および満塩・野田 ${ }^{5}$ に基づき,

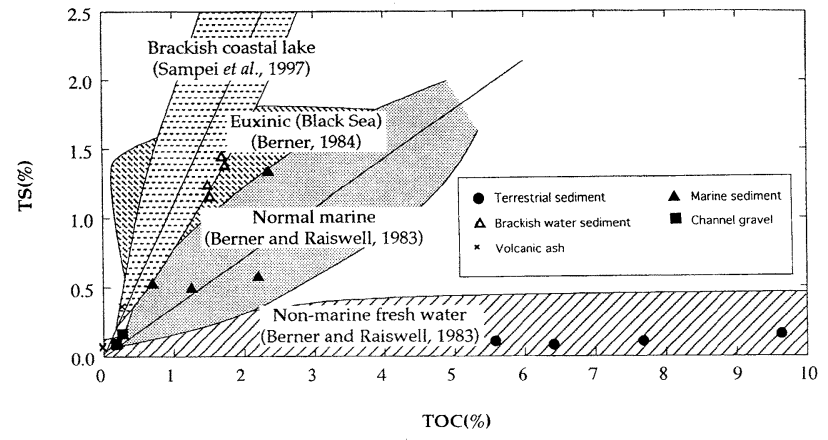

図-4 4 種類の堆積環境(淡水成，汽水成，海成，強還元性） 

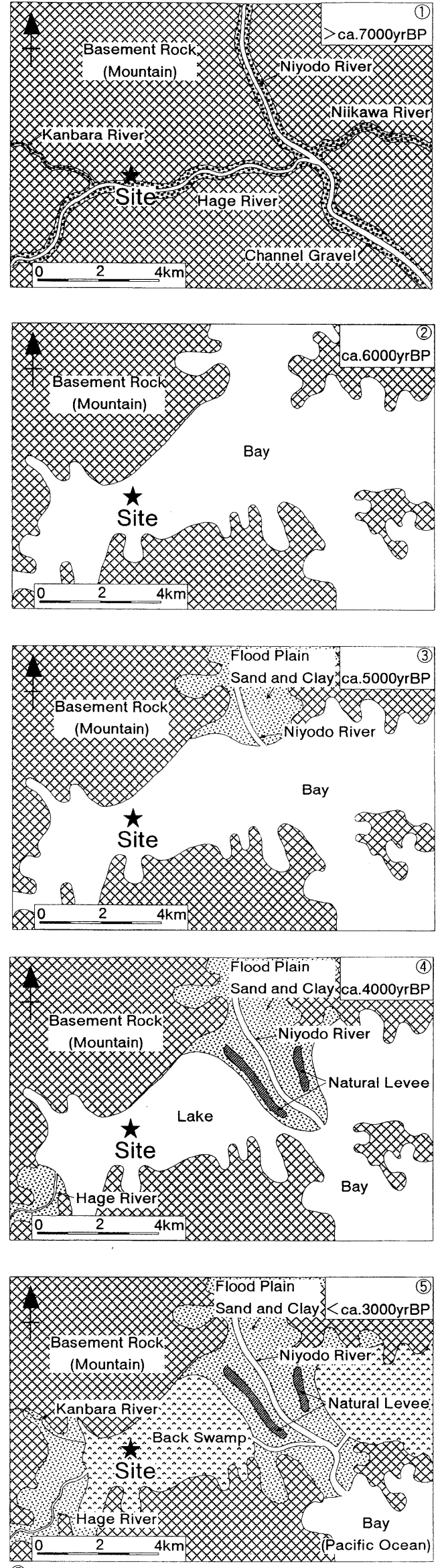

(5) is based on the present classification of landform.

図-5 高岡平野の環境変遷
G.L.

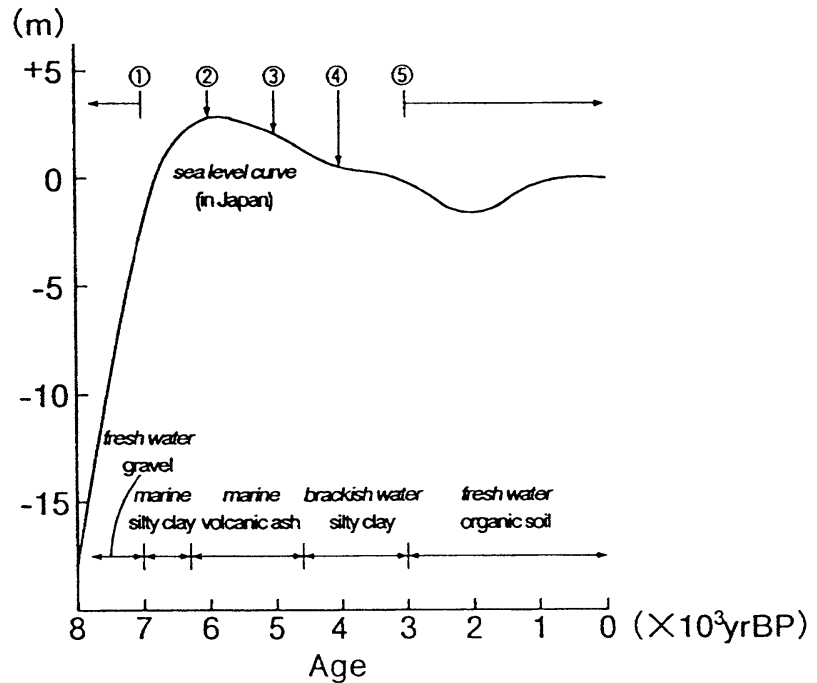

図-6 海水準変動曲線と堆積物 との関係(UMITSU (1991)に加筆)

ここでは高岡平野の形成過程および古環境変遷と海水準変 動 ${ }^{29)}$ に伴う現在に至るまでの堆積物との関係について考察 する.

約 1 万年前ごろから 6000 年まで続いた海進(縄文海進) により (図-5(1)，6(1)，河川の下流部は溺れ谷となる ${ }^{5)}$ されている. 深度 14〜 16.5m がこの時期の堆積物であり, $\mathrm{C} / \mathrm{N}$ 比(図-3(b)) は, 14〜16 という高い值であるので, 陸源物質の供給が多かったものと考えられる。したがって, 満塩・野田 ${ }^{5)}$ の結果をあわせると，この時期は，内湾のよ うな波の静かな環境下で, しかも陸源物質の供給の多い海 成粘土の堆積が起こったと推定される(図-5(2)). そして, 海進の最盛期(約 6300 年ごろ)に鬼界アカホヤ火山灰が降 下し(図-6(2)), 引き続き河川系からの火山灰の二次的な運 搬堆積作用によって火山灰質砂層が形成された(図-6(3)). 深度 14〜10.9m がこれに対応する堆積物である.

その後, 海退による海面の低下に伴い仁淀川の土砂運搬 作用が活発になり，河口付近では三角州が形成されたと考 えられている(図-5(3)). その後, 仁淀川の河床勾配が非常 に緩くなり，仁淀川の中〜下流域では自然堤防が形成され $た^{7)}$. その自然堤防の形成によって波介川や新川川支谷の 出口は次第に閉塞され，支谷底が湖沼になった ${ }^{6,7)}$ (図-5(4)). 図-2によれば，この時期にシルト質粘土が堆積したとな るが，今回の C N S 分析結果によればその堆積環境を付記 することができ，汽水成シルト質粘土が堆積した(図-6(4)) あのと推定できる．また， $\mathrm{C} / \mathrm{S}$ 比(図-3(b))を見ると，こ の時期は 1.2 前後であり, SAMPEI et $a$ l. $^{24)}$ によると, こ の時期は汽水成環境(閉鎖的環境)であったことを示してい る。このことからも，この時期の環境が湖沼のような閉鎖 的な環境であったと考えられる。

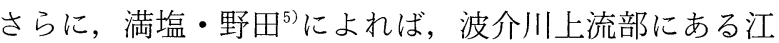
良沢付近に近い戸波村遺跡(弥生時代の遺跡)から相当数の 
土鍾が出土して扔り, 網漁が行われていたことから, 湖の 時代は，弥生時代ぐらいまであったと考えられる.

その後, 波介川は流域面積も狭く, 土砂運搬量が少ない ため，仁淀川との合流点付近に形成された自然堤防により， 海水之遮断され，波介川流域は沼沢地となったとみられ る ${ }^{7)}$ (図-5(5))。この時期に水生植物の遺体の堆積による陸 成層が形成される。 その後, 引き続く海退に伴って沼沢地 が陸化し，現在に至ると考えられる7)。そのため, この時 期は淡水成の有機質粘土が堆積した(図-6(5))。そして, 海 水面は現在之同じ高さまで上昇した。このような形成史を あつ地盤は一般に軟弱地盤で構成され，本流(仁淀川)から の汇濫水または本流への排出不良で冠水しやすいため，か っては湿地や湿田が多かった6). この地域でむ明治時代ま で江良沢付近に湿原が残留していた5).

\section{5. 結}

以下に，本研究により得られた主要な結果を列記する. (1)CNS 元素分析の結果から, 全硫黄・全窒素・全有機 炭素の深度分布を明らかにし，地球化学的データから堆積 環境の变遷を推定した。その結果, 堆積環境評価への地球 化学的解釈の有効性を指摘した.

(2)地球化学的分析(CNS 元素分析)の結果から明らかと なった堆積環境と本調査地域の地理(海水準変動)・地形・ 地史を総合的に考察し，高岡平野における縄文海進近傍か ら現在までの形成過程を TOC, TN, TS のデータに基づい て評価した。

謝辞 本研究を進めるにあたり，日本道路公団四国支社， (財)高速道路技術センター，不動建設(株)からは，土質試 料の提供と一連の土質試験結果を参考にさせていただいた. ここに，記して謝意を表します。

\section{引用 文 献}

1 ）亀井健史・徳岡隆夫 ・三瓶良和 - 石原廣和 (1997)：松江平野 の完新世堆積物の堆積環境と地盤工学的性質, 応用地質, Vol.38, No.5, pp.280-295.

2 ) 亀井健史・神田 貢・石原廣和 (1999）：出雲平野に招ける完 新世堆積物の堆積環境に関する学際的評価, 応用地質, Vol.40, No.2, pp.86-98.

3 ）石原廣和・亀井健史・中村唯史 (2000）：CNS 元素分析によ る出雲平野神西湖周辺の完新世堆積物の堆積環境評価とその 地盤工学への応用, 応用地質, Vol.41, No.1, pp.12-23.

4 ) 池田俊雄 (1982)：地盤之構造物 (自然条件に適応した設計へ のアプローチ), 鹿島出版会, 275p.

5 ）満塩大洸・野田耕一郎(1994）: 高知県土佐市の第四紀におけ る環境変遷一土佐市高岡平野，波介川流域の第四紀層一. 高 知大学学術研究報告, Vol.43, pp.101-114.

6 ) 日本地形学連合 (1996)：地形学加ら工学への提言. 古今書院, pp.32-33.
7 ) 高速道路技術センター(1997)：平成 8 年度高知自動車道土佐 地区軟弱地盤対策技術検討報告書, 133p.

8 ) 日本道路公団高松建設局高知工事事務所 (1997)：高知自動車 道北地工事のうち動態観測・土質調査結果資料(第 1 回).

9 ) 町田 洋・新井房夫 (1992)：火山灰アトラス[日本列島とそ の周辺], 東京大学出版会, $276 \mathrm{p}$.

10）谷山 穣・栗原権四郎・坂東祐司・横瀬広司・斎藤 実・西 嶋輝之(1968)：四国西部に扔ける音地火山灰層について. 香 川大学教育学部研究報告, Vol.173, pp.1-10.

11）町田 洋・新井房夫(1978): 南九州鬼界カルデラから噴出し た広域テフラーアカホヤ火山灰一. 第四紀研究, Vol.17, pp.143-163.

12) BERNER, R. A.(1982): Burial of organic carbon and pyrite sulfur in the modern ocean : Its geochemical and environmental significance, Amer. Jour. Sci., Vol.282, pp. 451-473.

13) BERNER, R. A.(1984): Sedimentary pyrite formation : An update, Geochim. Cosmochim. Acta, Vol.48, pp.605-615.

14）堀部純男・坪田博行 (1977)：海の中の物質の動き。海洋環境 の科学,東京大学出版会, pp.93-149.

15）中井信之・太田友子・藤澤 寛・吉田正夫 (1982)：堆積物コ アの炭素同位体比, $\mathrm{C} / \mathrm{N}$ 比打よび $\mathrm{FeS}_{2}$ 含有量からみた名古 屋港周辺の古気候, 古海水準変動. 第四紀研究, Vol.21, pp.169-177.

16）狛武・鈴木尉元・富樫茂子(1989）：南関東ガス田のいくつか の杭井堆積物を用いた地球化学的指標成分の研究，石油技術 協会誌, Vol.54, pp.1-17.

17) BERNER, R. A. and RAISWELL, R.(1983) : Burial of organic carbon and pyrite sulfur in sediments over Phanerozoic time : a new theory, Geochim. Cosmochim. Acta, Vol.47, pp.855-862.

18) BERNER, R. A. and RAISWELL, R.(1984): C/S method for distinguishing freshwater from marine sedimentary rocks. Geology, Vol.12, pp.365-368.

19) LIN, S. and MORSE J. W.(1991)：Burial of organic carbon and pyrite sulfur in the modern ocean : Its geochemical and environmental significance, Amer. Jour. Sci., Vol.282, pp.451-473.

20) MORSE, J. W. and BERNER, R. A.(1995): What determines sedimentary C/S ratios?. Geochim. Cosmochim. Acta, Vol.59, pp.1073-1077.

21) RAISWELL, R. and BERNER, R. A.(1986) : Pyrite and organic matter in Phanerozoic normal marine shales, Geochim. Cosmochim. Acta, Vol.50, pp. 1967-1976.

22) LENENTHAL, J. S.(1995) : Carbon-sulfur plots to show diagenetic and epigenetic sulfidation in sediments, Geochim. Cosmochim. Acta, Vol.59, pp.1207-1211.

23）三瓶良和 - 倉門由希子 - 清水紋 - 高安克己 - 石田聖(1997)： サロマ湖・網走湖底質の有機炭素・窒素・イオウ濃度, Res. Org. Geochem., Vol.12, pp.51-60.

24) SAMPEI, Y., MATSUMOTO, E., KAMEI, T. and TOKUOKA, T.(1997): Sulfur and organic carbon relationship in sediments from coastal brackish lakes in the Shimane peninsula district, southwest Japan. Geochem. Jour., Vol.31, pp.245-262.

25) BORDOVSKIY, O. K.(1965) Accumulation of organic matter in bottom sediments. Mar. Geol., Vol.3, pp.33-82.

26）南 秀樹・加藤義久・和田秀樹 - 岡部史郎(1995)：浜名湖の 
堆積物コア中の元素の分布と過去 1 万年間の環境変遷. 地球 化学, Vol.29,pp.85-97.

27）寺島 滋 - 稲積章生 - 石原瞬三 (1981): 中国, 四国地方の泥 質岩中の炭素之硫黄. 地質調查所月報, Vol.32, pp.167-181.

28) LYONS, T. W. and BERNER, R. A.(1992) : Carbon-sulfuriron systematics of the uppermost deep-water sediments of the Black Sea, Chemical Geology, Vol.99, pp.1-27.

29) Umitsu, M.(1991) : Holocene sea-level change and coastal evolution in Japan, The Quat. Res., Vol.30, pp.187-196.

（2001 年 5 月 10 日受付， 2001 年 9 月 12 日受理）

Jour. Japan Soc. Eng. Geol., Vol.43, No.1, pp.35-42, 2002

\title{
Evaluation of Depositional Environments of Holocene Deposits in the Takaoka Plain Based on Total Sulfur, Total Nitrogen and Total Organic Carbon Concentration
}

\author{
Takeshi KAMEI, Hirokazu ISHIHARA and Hideaki KONDO
}

\begin{abstract}
This paper describes an integrated study of the sedimentary environment of Holocene deposits in the Takaoka Plains(Kochi prefecture), southwest Japan. The geological history and geochemistry (total sulfur, total nitrogen and total organic carbon concentration) of Holocene deposits in the Takaoka Plain form the basis of the study. Total sulfur, total nitrogen and total organic carbon relationships in Holocene sediments have been used to characterize depositional environments, namely normal marine, brackish water and freshwater sediments. The weight ratio of organic carbon to pyrite sulfur (C/S ratio)and total sulfur(TS)are useful for evaluating sedimentary environments. To this end, CNS elemental analysis has led to a better understanding of sedimentary environments. The geological processes of Takaoka Plain with respect to sea level change during the Holocene is also presented.
\end{abstract}

Key words : CNS elemental analysis, Holocene, sedimentary environment 